\title{
PENGAMATAN PENDAHULUAN PERIODE PEMIJAHAN IKAN BO'TIA (Botia macracantbus) DI PERAIRAN SUNGAI BATANGHARI
}

\author{
Dadiek Prasetyo")
}

\begin{abstract}
ABSTRAK
Pengamatan pendahuluan periode pemijahan ikan Botia (Botia macracanthus) di perairan Sungai Batanghari dilaksanakan antara bulan April 1992 sampai dengan bulan Maret 1993 di perairan DAS Batanghari bagian hulu sampai dengan daerah hilir.

Hasil pengamatan menunjukkan bahwa periode pemijahan ikan botia selama tahun 1992/1993 hanya berlangsung pada bulan Desember, Januari dan Februari. Pemijahan berlangsung di perairan bagian tengah, sedangkan larva banyak ditemukan di bagian hilir sungai.

ABSTRACT: Preliminary Obecrvation of Spawning period of Botia (Botis mecrecosubus) in Batanghari riverine, by: Dadiek Prasetyo.

Preliminary observation on the spawning period of ornamental fish botia (Botia macracantbus) in Batanghari riverine was conducted during April 1992 to March 1993 in the up stream until down stream of Batanghari River basin.

The result of obsevation showed that spawning period of ornamental fish botia during 1992/1993 was only occurred on December, January and February. Spawning occured in middle stream, while the fish larvae mostly inhabited the down stream of the river.
\end{abstract}

KEYWORDS: Spawoning period, Botia, omamental fisb

\section{PENDAHULUAN}

Pemijahan ikan perairan umum, biasanya berlangsung hampir bersamaan, akan tetapi periode pemijahannya berbeda-beda, tergantung dari keseragaman tingkat kematangan gonad pada ikan botia dan lingkungan perairan. Menurut Samuel et al. (1993) tingkat kematangan gonad induk ikan botia yang didapatkan di DAS Batanghari bagian tengah pada bulan yang sama sangat bervariasi. Variasi tingkat kematangan gonad ini diperkirakan yang menyebabkan terjadinya periode pemijahan berbeda-beda.

Penyebaran ikan botia di perairan umum terdapat pada tipe perairan yang berbeda. Yang berukuran besar banyak menghuni perairan yang berarus agak deras ataupun banyak menghuni daerah sungai bagian tengah yang dasarnya sedikit berkerikil (middle stream), sedang anakannya banyak menghuni perairan bertipe banjiran (flood plain) yang berupa danau mati (oxbow lake) yang berada di bagian hilir (down stream), akan tetapi sifatnya hanya sementara.

7) Peneliti pada Loka Penelitian Perikanan Air Tawar Palembang 
Pola penyebaran tersebut di atas memberikan gambaran kepada kita bahwa siklus hidup ikan botia melangsungkan ruaya/migrasi baik dari hulu ke hilir sungai ataupun sebaliknya, hal ini dilakukan oleh anakan ikan botia yang baru saja menetas (larvae) sampai ukuran tertentu (ukuran kurang dari $8 \mathrm{~cm}$ ).

Menurut Prasetyo (1992) ikan botia yang berukuran di atas 3 inci bermigrasi dari daerah hilir sungai ke bagian tengah (midle stream) untuk kembali ke habitat aslinya. Habitat asli ikan botia adalah daerah bagian tengah sungai (midle stream) yang dipergunakan untuk kelangsungan hidup induk ikan botia, sedang habitat sementara adalah daerah asuhan sementara anakan ikan botia di daerah hilir. Ikan botia yang sudah berukuran besar (induk) tidak melakukan migrasi, baik saat melakukan pemijahan ataupun aktivitas yang lain (Kamal, 1992).

Musim penangkapan ikan botia di DAS Batanghari bagian hilir biasanya berlangsung antara bulan Desember sampai dengan bulan Maret. Kegiatan di atas biasanya bersamaan atau setelah musim pemijahan ikan botia di alam yang terdapat di DAS bagian tengah, tepatnya pada saat air mulai besar (mencapai puncak) sampai dengan air mulai menyurut (mengecil). Keadaan banjir merupakan faktor penentu keberhasilan pemijahan ikan perairan tropis (Brown, 1957). Produksi hasil tangkapan ikan botia di sungai Batanghari pada tahun 1987 menunjukkan penurunan yang cukup drastis, hal ini diperkirakan terjadinya musim kemarau yang panjang (Anonim, 1989).

\section{BAHAN DAN METODE}

Daerah pengamatan larva ikan botia dilakukan di daerah banjiran, antara lain Danau Mudung, Danau Sipin, Danau Arang Arang, daerah Dusun Mudo dan Danau Kenali. Untuk pengamatan ikan botia yang berukuran besar sampai induk dilakukan di DAS bagian tengah atau di Kecamatan Tebo Tengah, meliputi Desa Jambu, Pagar Puding, Ulak Bandung, Bento, Teluk Singkawang, Teriti dan Desa Putikalo.

Pengumpulan sampel larva ikan botia dilakukan 1 (satu) bulan sekali di perairan DAS Bagian hilir, yaitu pada bulan Desember, Januari, Februari dan Maret. Sampel diambil dari 4 stasiun pengamatan, dari setiap sampel di empat stasiun tersebut diambil 100 ekor untuk diukur panjangnya. Penangkapan larva ikan botia dilakukan dengan menggunakan alat tangkap tabung bambu dengan diameter $2,5 \mathrm{~cm}$. Aktivitas penangkapan ikan dilakukan pada malam hari kurang lebih pukul $18.00 \mathrm{~s} / \mathrm{d}$ 24.00. Penangkapan ikan yang berukuran besar sampai dengan ukuran induk (di DAS bagian tengah) dilakukan dengan alat tangkap jaring hanyut, jaring pukat, jala dan jaring kantong. Aktivitas penangkapan dilakukan pada siang dan sore hari. Pengumpulan data ikan botia yang berukuran besar sampai dengan induk dilakukan 2 bulan sekali selama periode April 1992 hingga Maret 1993, data yang dicatat adalah ukuran panjang dan tingkat kematangan gonad. 
Untuk mendukung penelitian musim pemijahan ikan botia dilakukan pengamatan tingkat kematangan gonad di DAS bagian tengah Sungai Batanghari, dengan mengambil sampel gonad ikan botia yang sudah dewasa sebanyak 5 ekor setiap kali pengamatan dan diamati di laboratorium.

Data tentang fluktuasi ketinggian air diambil dari Perum Pelabuhan Cabang Il Jambi, sedangkan data curah hujan diambil dari Dinas Pertanian Tanaman Pangan Tk.II Muara Bungo.

\section{HASIL DAN PEMBAHASAN}

\section{DAS Bagian Hulu dan Tengah}

Data sebaran ikan botia di berbagai tipologi perairan selama pengamatan dapat dilihat pada Table 1.

Table 1. Size distributions and somatic index of maturity of Botia macracanthus caught in different water tipology during 1992/1993

\begin{tabular}{|c|c|c|c|c|c|}
\hline \multirow{2}{*}{$\begin{array}{l}\text { Montbs of } \\
\text { Observation }\end{array}$} & \multirow{2}{*}{$\begin{array}{l}\text { Size } \\
(\mathrm{cm})\end{array}$} & \multirow{2}{*}{$\begin{array}{c}S I M \\
\text { (somatic } \\
\text { index } \\
\text { matwarty) }\end{array}$} & \multicolumn{3}{|c|}{ River Basin } \\
\hline & & & up stream & middle stream & docon stream \\
\hline April & $7.5-15$ & 0 & - & + & + \\
\hline June & $11-29.5$ & $I$ & - & + & - \\
\hline August & $15-27.5$ & $I I$ & - & + & - \\
\hline October & $20-28.5$ & $I I I$ & - & + & $\cdot$ \\
\hline December & $1 \cdot 3$ & - & - & - & + \\
\hline February & $0.5-6.5$ & - & - & $\cdot$ & + \\
\hline
\end{tabular}

Note: - No single fish was observed

+ The fish were present but not caught

SIM : Somatic index maturity (Nikolsky, 1963)

Sampel ikan botia yang tertangkap di perairan DAS Batanghari mempunyai kisaran ukuran antara $0,5-29,1 \mathrm{~cm}$, akan tetapi ikan yang berukuran $8 \mathrm{~cm}$ ke atas hanya tertangkap sampai dengan bulan Oktober, sedang pada bulan yang lain tidak didapatkan lagi.

Hasil pengamatan memperlihatkan bahwa induk botia matang gonad setelah mencapai ukuran minimal panjang $12,5 \mathrm{~cm}$, bobot $180 \mathrm{~g}$. Menurut Kamal (1992) ikan botia matang telurnya pada ukuran paling kecil $13 \mathrm{~cm}$. 
Sampel ikan botia yang diambil pada bulan April belum menunjukkan tingkat kematangan gonadnya. Perkembangan gonad mulai nampak pada bulan Juni (TKG I), Agustus (TKG II) dan pada bulan Oktober mencapai kematangan (TKG III) sedang pada bulan November sampai dengan Maret ikan sudah tidak didapatkan lagi (Table 1). Kemungkinan pada bulan tersebut sudah memijah. Bila dilihat dari sebaran larva dan benih di sungai bagian tengah dan hilir, maka dapat diperkirakan bahwa induk-induk botia memijah pada sungai bagian tengah pada bulan Desember.

Mulai bulan Desember ikan botia yang berukuran induk dan gonadnya sudah matang tidak didapatkan lagi, karena kondisi air sudah tinggi (Figure 1) di mana alat tangkap sudah tidak efektif lagi dioperasikan. Situasi ini sesuai dengan informasi nelayan yang menyatakan bahwa ikan botia yang akan memijah berada di lubuk (daerah perairan sungai yang dalam), sehingga sulit ditangkap dengan alat yang ada. Kemungkinan ikan induk tersebut sudah mulai memijah di daerah bagian tengah sungai Batanghari, akan tetapi anaknya dapat dilihat di daerah hilir, karena anakan ikan botia ini beruaya dari DAS bagian tengah ke hilir, tepatnya di perairan banjiran yang ada di daerah hilir.

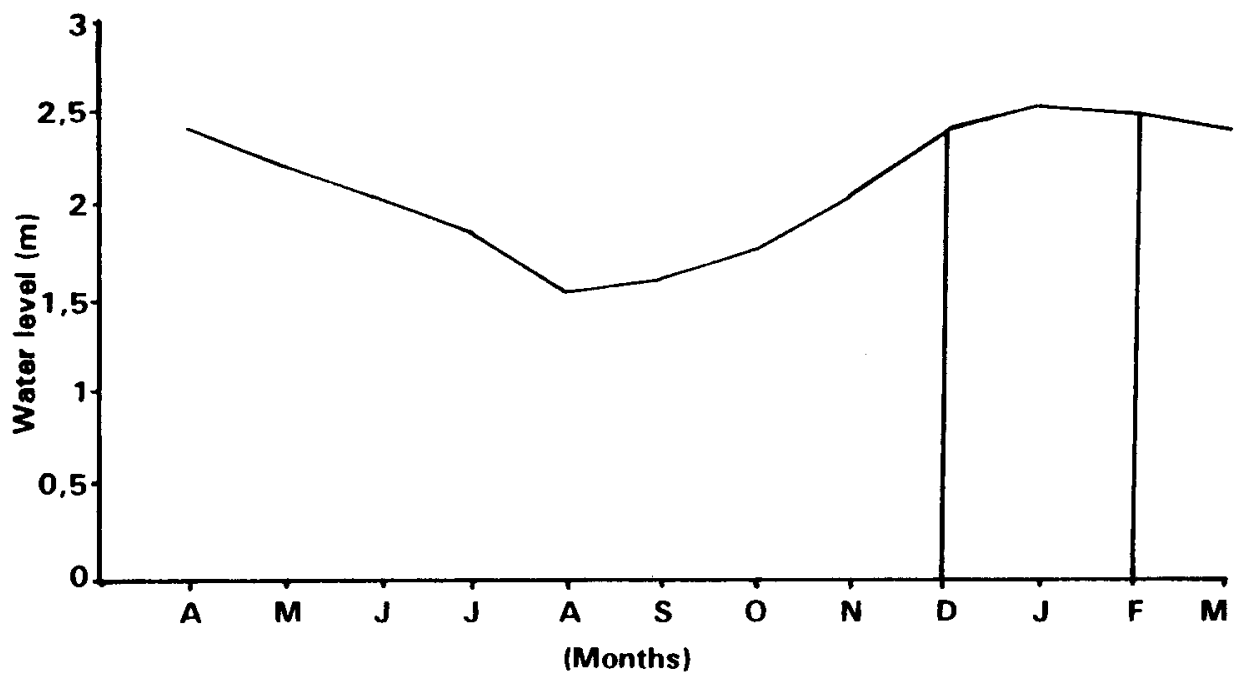

Figure 1. Correlation of water level and spawning period of Botia in Batanghari river basin during 1992/1993

Pemijahan ikan botia di alam berlangsung selama musim air besar, antara bulan Desember sampai dengan bulan Maret sehingga benihnya di alam banyak terdapat pada bulan-bulan tersebut. 
Prasetyo, $D$.

Pemeriksaan kualitas air selama musim kemarau di daerah hilir dan daerah tengah selama penelitian tidak menunjukkan perbedaan yang berarti, kecuali pH yang menunjukkan perbedaan, ini disebabkan oleh air rawa yang bersifat asam dan dominan masuk kebagian yang lebih dalam, sedang air sungai yang bersifat menetralisir belum dapat masuk ke dataran banjir karena level air masih rendah. Kualitas air di daerah hulu selama musim penghujan maupun kemarau tidak menunjukkan perbedaan yang menyolok, kemungkinan kualitas air yang demikian tidak berpengaruh terhadap aktivitas pemijahan ikan botia di alam (Table 2).

Table 2. Mean value of water quality parameter during wet and dry season in 1992/1993

\begin{tabular}{lcccc}
\hline \multirow{2}{*}{ Parameter } & \multicolumn{2}{c}{ Wet Season } & \multicolumn{2}{c}{ Dry Season } \\
\cline { 2 - 5 } & $\begin{array}{c}\text { Middle } \\
\text { stream }\end{array}$ & $\begin{array}{c}\text { Down } \\
\text { stream }\end{array}$ & $\begin{array}{c}\text { Middle } \\
\text { stream }\end{array}$ & $\begin{array}{c}\text { Down } \\
\text { stream }\end{array}$ \\
\hline Temperature $\rho C)$ & 28.5 & 27.5 & 28.5 & 27.5 \\
Transparancy (cm) & 43 & 45 & 50 & 45 \\
pH & 6.5 & 7 & 5.5 & 6.5 \\
DO (ppm) & 6.5 & 7 & 5.5 & 5.95 \\
Carbon dioxyde (ppm) & 7 & 6.5 & 7.5 & 6.5 \\
Acidity & 0.4 & 0.65 & 0.35 & 0.65 \\
Hardness & 25 & 47 & 20 & 45 \\
Alkalinity (ppm) & 25 & 35 & 15 & 30 \\
\hline
\end{tabular}

Di DAS bagian Tengah (Kabupten Bungo Tebo) nampak bahwa curah hujan yang tinggi terjadi antara bulan November sampai dengan bulan Maret. Bersamaan dengan curah hujan yang tinggi biasanya air di DAS bagian tengah mulai kelihatan banjir dan pada saat ini pula ikan botia memijah di alam. Menurut Brown (1957) pemijahan ikan di daerah tropis dipengaruhi oleh besarnya banjir yang berlangsung.

\section{DAS Bagian Hilir}

Penangkapan larva dimulai dari bulan April 1992 baru diperoleh sampai dengan bulan Maret 1993, akan tetapi larva ikan botia mulai bulan Desember 1992 sampai dengan Maret 1993.

Pada bulan Desember larva dan benih ikan botia yang ada di alam mempunyai kisaran ukuran $1-3 \mathrm{~cm}$ dan ukuran ini masih menunjukkan variasi yang kecil bila dibandingkan dengan bulan-bulan yang lain (Figure 2). Pada bulan tersebut pemijahan ikan botia masih pada periode awal, sehingga variasi ukuran ikan yang tertangkap di alam selama bulan tersebut belum begitu besar. 


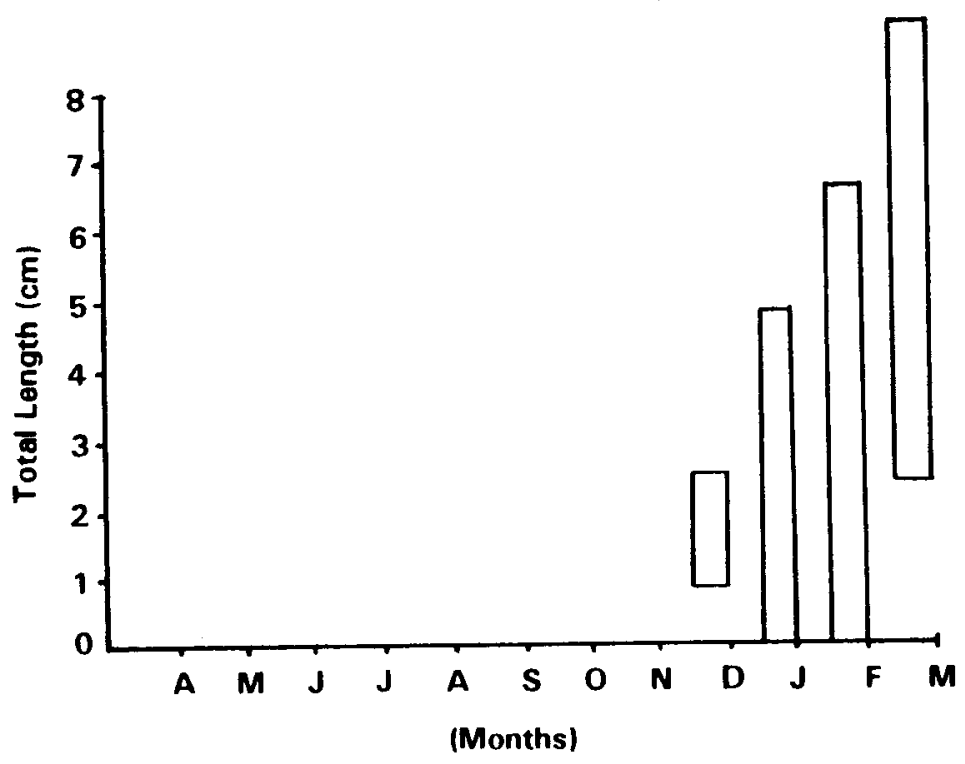

Figure 2. Size distribution of Botia during spawning 1992/1993

Pada awal bulan Desember biasanya air Sungai Batanghari baru akan mencapai puncak dan pada kondisi air yang demikian diperkirakan berlangsung pemijahan induk. Menurut Brown (1957) aktivitas pemijahan ikan di perairan umum sangat ditentukan oleh keadaan banjir. Hal di atas juga terlihat dari hasil tangkapan larva ikan botia yang bermigrasi dari daerah tengah sungai ke daerah hilir sungai atau di daerah banjiran bagian hilir.

Pada bulan Januari benih ikan botia yang tertangkap sudah mulai menunjukkan kisaran ukuran yang cukup besar, yaitu antara $0,5-5 \mathrm{~cm}$.

Pada bulan tersebut tampak terdapat variasi ukuran yang lebih besar dari bulan sebelumnya, ini menunjukkan bahwa ikan yang tertangkap pada bulan yang sebelumnya sudah mulai tumbuh, tetapi ada rekruitmen dari generasi baru berasal dari induk yang memijah setelah periode yang pertama. Menurut Samuel et al. (1994) induk ikan botia yang tertangkap di daerah bagian tengah Sungai Batanghari tingkat kematangan gonadnya berbeda-beda walaupun didapatkan dalam waktu yang sama. Hal tersebut menunjukkan bahwa pemijahan ikan botia di alam berlangsung beberapa kali, karena terdapat beberapa kelompok induk yang matang gonad secara berturut-turut.

Di samping tingkat kematangan gonad yang berbeda-beda pada bulan yang bersamaan, pemijahan ikan di perairan umum juga sangat dipengaruhi oleh 
Prasetyo, $D$.

keadaan banjir (tinggi air), mungkin ketinggian air yang masih bertahan sampai dengan bulan Februari merangsang terjadinya pemijahan dalam bulan tersebut (Figure 1, 2). Bahkan pemijahan dan benih ikan botia kadang-kadang masih dijumpai sampai saat air mulai menyurut.

Dalam bulan Februari dijumpai variasi ukuran dalam populasi ikan botia yang tertangkap sudah cukup besar, yaitu 0,5-6,5 cm. Ini menunjukkan bahwa pada bulan Februari terjadi lagi pemijahan baru dari induk-induk yang ada di bagian hulu (Figure 1).

Jadi dari bulan Januari sampai dengan Februari terjadi 3 periode pemijahan sesuai dengan gerakan kenaikan tinggi air di sungai yang mulai pada bulan Januari sampai dengan bulan Februari (Figure 1, 2). Periode ini setiap tahun mempunyai pola yang berbeda-beda, biasanya tergantung dari gonad yang matang dan lingkungan perairan khususnya keadaan banjir di DAS tersebut.

Pada bulan Maret ukuran benih ikan botia yang didapatkan mempunyai ukuran $2-7,5 \mathrm{~cm}$ dan tidak terdapat lagi ukuran di bawah $2 \mathrm{~cm}$. Hal ini menunjukkan bahwa pada bulan Maret sudah tidak terjadi lagi rekruitmen larva yang baru. Ikan botia yang sudah berukuran cukup besar ini biasanya sudah mulai melakukan migrasi ke daerah hulu. Kejadian semacam ini biasanya diikuti dengan kondisi air yang mengecil atau mulai menyurut. Bersamaan dengan mulai surutnya air pada akhir bulan Maret tampaknya berakhir pula pemijahan induk-induk botia.

\section{KESIMPULAN}

Periode pemijahan ikan botia pada tahun 1992/1993 berlangsung 3 kali, yaitu bulan Desember 1992, Januari 1993 dan Februari 1993. Musim pemijahan ini setiap tahun bisa berubah maju atau mundur tergantung dari kondisi ketinggian air di sungai. Pemijahan berlangsung di perairan sungai Batanghari bagian tengah saat air besar, sedang larva ikan botia ada di bagian hilir sungai Batanghari saat air besar.

\section{DAFTAR PUSTAKA}

Anonimous. 1989. Produksi ikan hias propinsi Jambi Th. 1987 dan Kondisi air sungai Batanghari. Laporan Teknis Dinas Perikanan Tk. I Jambi. 54 hal.

Brown, M.E. 1957. The physiology of fishes. Department of zoology Kings College. London.

Kamal. M.M, 1992. Biologi ikan Botia (Botia macracanthus) di sungai Batanghari Jambi. Skripsi Fakultas Perikanan IPB. 
Prasetyo. D. 1992. Aktifitas penangkapan ikan botia di Danau Arang-arang Jambi. Laporan Intern Sub Balitkanwar Palembang.

Samuel, D. Prasetyo dan Akrimi, 1994. Distribusi dan biologi ikan botia (Botia macracantbus) di DAS Batanghari Jambi. Kumpulan makalah hasil penelitian Sub Balitkanwar Palembang. 